\title{
Improving informed consent in cardiology practice: How much we need to do
}

\author{
Hadi Khafaji*, Haneen Al-Gerrah and Asim Cheema \\ Department of Cardiology, Saint Michael's Hospital, Toronto University, Canada
}

\begin{abstract}
Cardiology interventions remain to be complex and difficult to understand by the general people. Consent requirements have become gradually challenging in parallel to the rise of autonomy as a dominant principle in biomedical ethics in addition to the complexity of cardiology intervention. Studies showed that patients have suboptimal understanding of the procedural risks and benefits.
\end{abstract}

Many novel elucidations have been offered to enhance informed consent, many of which have narrowed, although not eradicated, the gap in attaining proper informed consent goals and objectives. The current review will discuss the up to date available studies that have investigated this important subject in cardiology.

\section{Introduction}

Consent is among the most broadly deliberated issues in up-todate biomedical ethics, and is progressively important in the cardiology practice. Consent requirements have become progressively demanding in parallel to the rise of autonomy as a dominant principle in biomedical ethics that need to parallel the legal demands to be more clear and specific, these demand may be difficult to be achieved specially in the setting of emergency situation like the primary angioplasty. Keeping in consideration the complexity of modern advances in medical treatment make it difficult even for fully competent patients giving truly informed consent [1].

There is severe argument that the disparity between the obligation for the consent to be fully specific and fully unequivocal and what is persuasively attainable may persists, and to eliminate this disparity reconsideration of prevailing lawmaking and medical strategies is needed. Focusing on effectual communication and a proportionate and individualized approach for cardiology practice informed consent could have impact in this subject.

Cardiology interventions remain to be complex and difficult to understand by the general people in different communities. When it comes to life saving procedures like primary coronary intervention or coronary artery bypass grafting, during emergency situations and with the limited time for patients to decide upon consenting for the procedure or not, it is still a challenge to the treating medical staff to let the patients truly understand all the aspects of the procedure before stepping into the catheterization lab or operation room.

In addition, to obtaining an informed consent a certain criteria has to be met, and with the complexity of the procedures this adds to the complexity of the consent which makes it truly exigent for doctors to fulfill all the requirements for achieving an informed consent. How much do patients understand when they sign the consent for primary coronary intervention procedure? Do they truly comprehend the risks and benefits of the procedure being done? How well are the components of informed consent fulfilled by physicians? Is alternative treatment laid clearly for patients to choose from? Do we need to make alterations to our standard practices to achieve better patients' understanding and satisfaction? All of those questions are still ought to be answered and so our current book chapter looked at the studies done to date to assess how well patients understand the risks and benefits of primary coronary intervention after a consent has been taken.

\section{The component of informed consent}

Informed consent requirements now pervade through decree, common law and guidelines, such requirements should meet the criteria of adequate understanding through satisfactory evidence for the planned treatment, and compulsion free decision [2,3]. The following component of to be fulfilled;

1. The sufficient information component: The information to be given to the patient should be complete and detailed to clarify the risks and benefits of the proposed treatment, this component represent a general legal and ethical principle needed for the valid consent to be obtained before starting treatment or physical investigation or providing personal care, this principle is agreed on by all regulatory medical societies in Europe and north America [4-6].

2. Adequate understanding component: This needs adequate mental state and proper language comprehension that enable patient to make a decision. Legally patient cannot make decision unless he or she fully understand the information related to treatment or procedure and able to recall the information, balance the risks and benefits and communicate that information as part of the decision making process [7].

*Correspondence to: Hadi AR Hadi Khafaji, FRCP Glasgow, Cardiology Department Saint Michael's Hospital, Toronto University, Canada, Tel: +971 50 8192544; E-mail: Hadi968@hotmail.com,hadiarhadi@yahoo.com

Key words: informed consent, coronary intervention

Received: May 14, 2018; Accepted: May 24, 2018; Published: May 28, 2018 
3. Compulsion free component: It is an ethical and legal issue that consent should be given in full freedom after the above 2 component has been fulfilled.

Informed consent requirements have become gradually laborious. And efforts aimed at making consent more precise unambiguous result in that the consent forms have become increasingly complex, detailed and lengthy, including more and more risks. Nevertheless, with increasing complexity of cardiology treatments and interventions such meticulous consent may not be feasible.

\section{Limitation of informed consent}

Till to date and with increasing complexity of the scientific data related to coronary intervention and specifically to coronary angioplasty both in its elective and primary forms has exerted many limitations for the informed consent to be obtained these can be summarized into:

\section{Amount of the information to be given}

The information requirement for valid informed consent is matter of controversy: the information supplied to the patient for coronary intervention should be clear, objective not subjective, recent evidenced based and should be patient oriented, comprehensible, consistent, reachable, relevant and legislative [4].

The amount of information to be given to the patient is also variable and many studies had shown that the patient prefers to be informed about all the risk and befits of the procedure [8-10], while other group of patients complained that the information is an overload on their ability for decision making and prefer to be waived from the informed consent process especially in the setting of acute unexpected illness like the myocardial infarction [11].

\section{Proper patient comprehension}

This gap in informed consent is the most difficult to achieve as it patient dependent and it is most variable in the setting of acute myocardial infarction were the anxiety, distress, pain, in addition to effect of administered sedation or opiates, and impaired mentation as result of impaired cerebral perfusion as part of hemodynamic instability in acute setting [12-14].

Keeping in mind regularly advancing cardiology literature and increasingly complicated and cognitively demanding interventions, and the result is that appropriate informed consent is only rarely achieved all these limitation all these has encouraged some institutions to adopt a system that utilizes "assent": a truncated form of the desired consent process justified to act in the patient's best interest but it can be understood as a slippery slope to authoritarianism.

While in elective coronary intervention fewer than $50 \%$ of such patients understand the causes or consequences of an AMI or stroke in the same way, it has been argued that patients may be excessively optimistic about the benefits of elective angioplasty (Table 1) [9,15-27].

Furthermore, the Information comprehension is not limited to patients, and also may be applied to caregivers. Excessive pessimism regarding the survival of medically managed patients, and excessive optimism regarding the mortality benefit of revascularization has been demonstrated on analysis Conference delegates' opinion regarding the survival probability for medically managed patients with coronary artery disease, and the potential mortality benefit of CABG or PCI in such patients [28].

\section{Compulsion elimination}

In current practice cardiologists may introduce bias in cardiology treatment, and may Target points out, this means options for PCI are likely to be considered before surgery, and patients may get insufficient information or not offered potentially more effective alternative therapies While it is not credible that doctors would exert undue influence on patients, cardiologists may not be acquainted with recent progresses in cardio-thoracic practice, the same applied to the surgeons who may not be fully aware of interventional techniques. All this may muddles attempts to supply the precise and obvious information that is required of up-to-date medical practice [19].

\section{Perspectives of the informed consent in cardiology practice:}

As discussed above there is breach between reality and applying standard informed consent to fill this gap few theoretical suggestions are there:

1. To review the process of informed consent in a trial to make it balanced, feasible, attainable, and justified process. Such approach will necessitate collaboration between judicial bodies, governing bodies, specialist societies and it may be the preferred approach and the most difficult to achieve.

2. Upgrade the present consent process to meet the development of complex evidence-based cardiology guidelines this will require more demanding protocol and may more difficult than the first option.

3. Proceed on the present course, and neglect the present paucities keeping in mind the superficiality of the present form of informed consent.

Many novel solutions have been proposed to improve informed consent, many of which have narrowed, although not obliterated, the gap these include Multimedia presentation [29-31]. Telephone, e-mail and text message [32], Information leaflet [33], Health-literacy based consent form designed to facilitate two-way discussion between doctor and patient [34], Providing patients with audiotape recording of their pre-operative consultation [35], Interactive computer based information presentation [36] and Video presentation [37], consultation of patient groups [38], testing the scripted verbal or written consent versus web-based, audiovisual presentation [39], continuous consent, whereby information is given gradually over a period of time [40], prospective informed consent in high-risk groups [41], community consultation on appropriate means of obtaining consent [42]. The evidence for such solutions is inadequate as far as these studies lack of blinding, in addition to publication bias. Make evaluation of the above mentioned methods challenging (Table 2). Some studies compared the standard methods (ex: information leaflet) of explaining the procedure to patients to more explicit methods (ex: pre-procedure presentation or video or computer based information program or audio taping) prior the procedure and prior to patients signing the consent. Those studies collectively concluded that alternative methods and strategies seemed to improve patients' knowledge and perception regarding the procedure they are doing and recommended trending towards using those methods instead of the standard methods. A questionnaire with or without an interview was the method used by most studies to assess patients' perception and understanding of the procedure. The majority of studies were observational with the expected heterogeneity.

Providing patients with information regarding the health condition and treatment options (benefits, risks and uncertainties) help the 
Table 1. Studies that have tested the patient understanding of given information for informed consent in cardiology practice. CA: coronary angiography, PCI: percutaneous coronary intervnsion, HERO-1: hirulog early reperfusion/occlusion study, CABG: Coronary artery bypass grafting.

\begin{tabular}{|c|c|c|c|c|c|c|c|}
\hline Author & Year & Country & $\begin{array}{l}\text { Patient } \\
\text { included }\end{array}$ & Intervention & Study aim & Assessment used & Conclusion \\
\hline Kureshi F [27] & 2014 & USA & 991 & PCI & $\begin{array}{l}\text {-Assess the perceptions of patients with } \\
\text { stable CAD about the benefits of elective } \\
\text { PCI and assess how they vary across } \\
\text { centers. }\end{array}$ & Interview & $\begin{array}{l}\text {-Patients have poor understanding of the } \\
\text { benefits of elective PCI with significant } \\
\text { variation across sites. }\end{array}$ \\
\hline $\begin{array}{l}\text { Chandrase- } \\
\text { kharan DP [19] }\end{array}$ & 2011 & UK & 1476 & $\mathrm{PCI} / \mathrm{CABG}$ & $\begin{array}{l}\text {-Understand the aims of the proposed } \\
\text { intervention. } \\
\text {-Whether alternative effective therapies } \\
\text { were offered. }\end{array}$ & $\begin{array}{l}\text { Systematic review } \\
\text { of Medline for } \\
\text { observational studies }\end{array}$ & $\begin{array}{l}\text {-Many patients have wrong expectations of } \\
\text { their proposed coronary intervention and } \\
\text { discussion of more effective alternative } \\
\text { interventions wasn't accomplished. }\end{array}$ \\
\hline Eran A [18] & 2010 & Germany & 200 & $\begin{array}{l}\text { Coronary } \\
\text { Angiography }\end{array}$ & $\begin{array}{l}\text {-Knowledge differences between optimally } \\
\text { informed in-patients versus outpatients } \\
\text { immediately before CA. }\end{array}$ & $\begin{array}{l}\text { Interview with } \\
\text { questionnaire }\end{array}$ & $\begin{array}{l}\text { - The knowledge of patients is vague. } \\
\text {-Structured information given by a specially } \\
\text { trained physician did not increase this } \\
\text { knowledge. }\end{array}$ \\
\hline Ozkan O [25] & 2008 & Turkey & 60 & PCI & $\begin{array}{l}\text {-Evaluate patient's perspective about } \\
\text { treatment benefits before and after PCI. }\end{array}$ & $\begin{array}{l}\text { Interview with } \\
\text { questionnaire }\end{array}$ & $\begin{array}{l}\text {-Majority of patients had wrong expectation } \\
\text { regarding their PCI. }\end{array}$ \\
\hline Lee J [26] & 2008 & US & 498 & PCI & $\begin{array}{l}\text {-Investigate patients' perceptions of benefit } \\
\text { from elective PCI. }\end{array}$ & Questionnaire & $\begin{array}{l}\text {-Patients' perceived benefits of an elective PCI } \\
\text { do not match existing evidence. }\end{array}$ \\
\hline $\begin{array}{l}\text { Larobina ME } \\
{[24]}\end{array}$ & 2007 & Australia & 90 & $\mathrm{PCI} / \mathrm{CABG}$ & $\begin{array}{l}\text {-Evaluate patients' understanding of } \\
\text { the medical concept \& risks of the } \\
\text { intervention. } \\
\text {-Evaluate medical staff's understanding of } \\
\text { medical negligence and informed consent. }\end{array}$ & $\begin{array}{l}\text { Interview with } \\
\text { questionnaire }\end{array}$ & $\begin{array}{l}\text {-Patients have poor understanding of their } \\
\text { disease as well as the intervention. } \\
\text {-PCI patients were highly optimistic regarding } \\
\text { the need for re-intervention over time. }\end{array}$ \\
\hline Whittle J [16] & 2007 & USA & 633 & $\mathrm{PCI} / \mathrm{CABG}$ & $\begin{array}{l}\text {-Assessed patient beliefs about the benefits } \\
\text { of a proposed coronary revascularization. } \\
\text { Whether that belief was similar to } \\
\text { the -expected benefit reported by the } \\
\text { physician. }\end{array}$ & $\begin{array}{l}\text { Interview with } \\
\text { questionnaire }\end{array}$ & $\begin{array}{l}\text {-Patients have more optimistic expectations } \\
\text { about benefits of coronary revascularization } \\
\text { than the cardiologist offering the procedure. }\end{array}$ \\
\hline Vohra H [23] & 2003 & UK & 82 & Cardiac surgery & $\begin{array}{l}\text {-Determine the extent to which the } \\
\text { consent is informed, in line with standard } \\
\text { guidelines. } \\
\text {-Assess patient satisfaction with the } \\
\text { consent process for cardiac surgery. }\end{array}$ & Questionnaire & $\begin{array}{l}\text {-Patients were generally satisfied and well } \\
\text { informed about the procedure. } \\
\text {-Less information was presented about } \\
\text { alternative treatments, future lifestyle and } \\
\text { medications. }\end{array}$ \\
\hline Holmboe E [22] & 2000 & US & 52 & PCI & $\begin{array}{l}\text {-Assess reasons why patients undergo } \\
\text { elective PCI. } \\
\text {-Assess patient's understanding \& } \\
\text { expectations of PCI benefits and risks. }\end{array}$ & $\begin{array}{l}\text { Telephone interview } \\
\text { with questionnaire }\end{array}$ & $\begin{array}{l}\text {-Majority of patients had unrealistic } \\
\text { expectations about long-term benefits of PCI } \\
\text { and was not aware of the potential risks. }\end{array}$ \\
\hline Kimble L [21] & 1998 & US & 62 & PCI & $\begin{array}{l}\text {-Assess patients' perceptions of risks \& } \\
\text { benefits of PCI in the early post discharge } \\
\text { recovery period. } \\
\text {-Determine whether selected demographic } \\
\text { and clinical variables were associated with } \\
\text { patients' perceptions. }\end{array}$ & $\begin{array}{l}\text { Telephone interview } \\
\text { with questionnaire }\end{array}$ & $\begin{array}{l}\text {-More emphasis should be placed to help } \\
\text { patients predict and manage treatment side } \\
\text { effects and to have realistic expectations } \\
\text { concerning the course of recovery from PCI. }\end{array}$ \\
\hline Kee F [20] & 1997 & UK & 150 & PCI & $\begin{array}{l}\text {-Describe what cardiac patients understand } \\
\text { about the benefits of PCI } \\
\text {-Assess the extent to which they have been } \\
\text { able to make informed choices. }\end{array}$ & $\begin{array}{l}\text { Interview with } \\
\text { questionnaire }\end{array}$ & $\begin{array}{l}\text {-Patients vastly overvalue the capability of } \\
\text { PCI to control their disease. } \\
\text {-PCI is seen as more effective than risk factor } \\
\text { modification. }\end{array}$ \\
\hline $\begin{array}{l}\text { Williams BF } \\
{[15]}\end{array}$ & 1997 & $\begin{array}{l}\text { New } \\
\text { Zealand }\end{array}$ & 58 & Medical/PCI & $\begin{array}{l}\text {-Evaluate the suitability and } \\
\text { comprehension of the consent procedure } \\
\text { in patients invited to participate in the } \\
\text { HERO- } 1 \text { study }\end{array}$ & Questionnaire & $\begin{array}{l}\text { The understanding of acute written informed } \\
\text { consent was suboptimal. }\end{array}$ \\
\hline
\end{tabular}

patient recognize the value-sensitive nature of the decision, and provide a structured framework for the decision-making process improved the active involvement of patients in the decision-making in regards to the knowledge of treatment options, reduced decisional conflict related to feeling uninformed and unclear about personal values [43].

Furthermore using consent waiver in emergency situations and informed patients and relatives afterwards could reduce time to treatment, though this is a topic of severe argument and had limited value in fully conscious acute myocardial infarction patient and even with diminished capacity, patient and family need to be involved in the decision-making process [44-46]. Multidisciplinary decision making by the Heart Team a clinical/non-invasive cardiologist, interventional cardiologist and if needed a cardiac surgeon has been encouraged in an effort to improve informed consent.

\section{Conclusion}

Throughout our review, we noted that majority of studies showed that patients have suboptimal understanding of the procedural risks and benefits. Patients had unrealistic expectations about the benefits of the procedure as concluded by some studies. In addition, most studies also showed that patients were poorly informed about alternative treatments options. The key to ensuring effective informed consent is excellent communication. That being intelligible, relevant and adequately accurate and if consent is considered as merely as the disclosure of increasingly specific and explicit information, it frequently fails. More effort should be spent to improve the delivery of information to patients prior to consent signing and to ensure proper understanding of the risks and benefits of the procedure. 
Table 2. Studies that have tested some of the suggested methods to improve informed consent in cardiology practice. CA: coronary angiography, PCI: percutaneous coronary intervention, CABG: Coronary artery bypass grafting.

\begin{tabular}{|c|c|c|c|c|c|c|c|}
\hline Author & Year & Country & $\begin{array}{l}\text { Patient } \\
\text { included }\end{array}$ & Intervention & Study aim & Assessment used & Conclusion \\
\hline $\begin{array}{l}\text { Dathatri S } \\
\text { [39] }\end{array}$ & 2014 & USA & 102 & PCI & $\begin{array}{l}\text {-To compare the effectiveness of scripted verbal } \\
\text { or written consent versus web-based, audiovisual } \\
\text { presentation to enhance patients' knowledge of } \\
\text { the standard consent elements. }\end{array}$ & Questionnaire & $\begin{array}{l}\text {-Both pre-procedural educational approaches } \\
\text { improved patients' comprehension } \\
\text {-Important patient misperceptions regarding } \\
\text { PCI-related outcomes and alternatives persist, } \\
\text { independent of informed consent approach. }\end{array}$ \\
\hline $\begin{array}{l}\text { Verges M } \\
{[33]}\end{array}$ & 2011 & France & 34 & $\begin{array}{l}\text { Coronary } \\
\text { Angiography }\end{array}$ & $\begin{array}{l}\text {-Evaluate the efficacy of the procedure } \\
\text { information leaflet. }\end{array}$ & Questionnaire & $\begin{array}{l}\text {-Knowledge of modalities, profits and risks } \\
\text { are very low. } \\
\text {-The information leaflet improves knowledge } \\
\text { about the complications. }\end{array}$ \\
\hline $\begin{array}{l}\text { Mishra PK } \\
{[34]}\end{array}$ & 2010 & UK & 84 & CABG & $\begin{array}{l}\text {-Evaluate audiotaping outpatient consultations on } \\
\text { informed consent for cardiac surgery. }\end{array}$ & $\begin{array}{l}\text { Interview with } \\
\text { Questionnaire }\end{array}$ & $\begin{array}{l}\text {-Providing an audiotaped recording of } \\
\text { the consultation before cardiac surgery } \\
\text { appears to improve patients' knowledge and } \\
\text { perceptions. }\end{array}$ \\
\hline Tait AR [36] & 2009 & USA & 135 & PCI & $\begin{array}{l}\text {-Evaluate the effect of an interactive computer- } \\
\text { based information program on patients' } \\
\text { understanding of PCI. }\end{array}$ & $\begin{array}{l}\text { Interview with } \\
\text { questionnaire }\end{array}$ & $\begin{array}{l}\text {-The assessed program may be more } \\
\text { effective than written consent information in } \\
\text { improving patient understanding. }\end{array}$ \\
\hline $\begin{array}{l}\text { Steffenino G } \\
{[37]}\end{array}$ & 2007 & Italy & 108 & $\begin{array}{l}\text { Coronary } \\
\text { Angiography }\end{array}$ & $\begin{array}{l}\text {-Effectiveness of video-based presentation in } \\
\text { addition to the standard information sheet was } \\
\text { assessed. }\end{array}$ & Questionnaire & $\begin{array}{l}\text {-The video presentation was welcomed as } \\
\text { it familiarized patients with the cath-lab } \\
\text { environment as well as the technical aspects } \\
\text { of the procedures. }\end{array}$ \\
\hline
\end{tabular}

Videos presentation, computer-based information program through universal website hold great promise. More research needs to be done to assess the best mean of delivering information to patients keeping in consideration the intellectual and educational differences between patients in communities. Currently oral information given to the patient by clinician through formal training and supervision is preferable to written information and achieve better understanding of the information is related to discussion duration of more than 5 minutes at the time of consent and if needed it may be more productive to replace complex and arbitrary consent forms with documentary evidence of satisfactory communication that take in consideration the challenging legal requirements in contemporary practice.

\section{References}

1. Manson NC, O'Neill O (2017) Rethinking informed consent in bioethics. Cambridge University Press, Cambridge, New York xiv: 212.

2. Stauch M, Wheat K, Tingle J (2011) Text, cases and materials on medical law and ethics. (4th Edn) Routledge, New York

3. Beauchamp TL, Childress JF (2009) Principles of biomedical ethics. (6th Edn) Oxford University Press; New York xiii: 417.

4. Wijns W, Kolh P, Danchin N, Di Mario C, Falk V, et al. (2010) Guidelines on myocardial revascularization. Eur Heart J 31: 2501-2555.

5. http://www.ombudsman.org.uk/_data/assets/pdf file/0016/1096/Consent-incardiacsurgery.pdf

6. http://www.dh.gov.uk/en/Publicationsandstatistics/Publications/ PublicationsPolicyAndGuidance/DH_103643

7. http://www.legislation. gov.uk/ukpga/2005/9/contents

8. Liao L (2007) Benefits of coronary revascularization: a failure to communicate. $\mathrm{Am}$ Heart $J$ 154: 613-614. [Crossref]

9. Larobina ME, Merry CJ, Negri JC, Pick AW (2007) Is informed consent in cardiac surgery and percutaneous coronary intervention achievable? ANZ J Surg 77: 530-534. [Crossref]

10. Ende J, Kazis L, Ash A, Moskowitz MA (1989) Measuring patients' desire for autonomy: decision making and information-seeking preferences among medical patients. J Gen Intern Med 4: 23-30. [Crossref]

11. Agård A, Hermerén G, Herlitz J (2001) Patients' experiences of intervention trials on the treatment of myocardial infarction: is it time to adjust the informed consent procedure to the patient's capacity? Heart 86: 632-637. [Crossref]
12. Smithline HA, Mader TJ, Crenshaw BJ (1999) Do patients with acute medical conditions have the capacity to give informed consent for emergency medicine research? Acad Emerg Med 6: 776-780.

13. Yuval R, Halon DA, Merdler A, Khader N, Karkabi B, et al. (2000) Patient comprehension and reaction to participating in a double-blind randomized clinical trial (ISIS-4) in acute myocardial infarction. Arch Intern Med 160: 1142-1146.

14. Williams BF, French JK, White HD; HERO-2 consent substudy investigators (2003) Informed consent during the clinical emergency of acute myocardial infarction (HERO-2 consent substudy): a prospective observational study. Lancet 361: 918-922. [Crossref]

15. Williams BF, French JK, White HD (1997) Is our method of obtaining consent appropriate for randomised controlled trials in acute myocardial infarction? $N \mathrm{Z} \mathrm{Med}$ J 110: 298-299.

16. Whittle J, Conigliaro J, Good CB, Kelley ME, Skanderson M (2007) Understanding of the benefits of coronary revascularization procedures among patients who are offered such procedures. Am Heart $J$ 154: 662-668. [Crossref]

17. Boden WE, O'Rourke RA, Teo KK, Hartigan PM, Maron DJ, et al. (2007) Optimal medical therapy with or without PCI for stable coronary disease. $N$ Engl J Med 356: 1503-1516. [Crossref]

18. Eran A, Erdmann E, Er F (2010) Informed consent prior to coronary angiography in a real world scenario: what do patients remember? PloS ONE 5: e15164.

19. Chandrasekharan DP, Taggart DP (2011) Informed consent for interventions in stable coronary artery disease: problems, etiologies, and solutions. Eur J Cardiothorac Surg 39: 912-917. [Crossref]

20. Kee F, McDonald P, Gaffney B (1997) Risks andbenefits of coronary angioplasty: the patients perspective: a preliminary study. Qual Health Care 6: 131-139

21. Kimble LP, King KB (1998) Perceived side effects and benefits of coronary angioplasty in the early recovery period. Heart Lung 27: 308-314. [Crossref]

22. Holmboe E, Fiellin D, Cusanelli E, Remetz M, Krumholz H (2000) Perceptions of benefit and risk of patients undergoing first-time elective percutaneous coronary revascularization. $J$ Gen Intern Med 15: 632-637.

23. Vohra H, Ledsham J, Vohra H, Patel R (2003) Issues concerning consent in patients undergoing cardiac surgery-the need for patient-directed improvements: a UK perspective. Cardiovasc Surg 11: 64-69

24. Larobina ME1, Merry CJ, Negri JC, Pick AW (2007) Is informed consent in cardiac surgery and percutaneous coronary intervention achievable? ANZ J Surg 77: 530-534. [Crossref]

25. Ozkan O, Odabasi J, Ozcan U (2008) Expected treatment benefits of percutaneous transluminal coronary angioplasty: the patient's perspective. Int J Cardiovasc Imaging 24: 567-575. 
26. Lee J, Chuu K, Spertus J, O'Keefe J (2008) Widespread patient misconceptions regarding the benefits of elective percutaneous coronary intervention. Circulation 118: S_1161.

27. Kureshi F, Jones PG, Buchanan DM, Abdallah MS, Spertus JA (2014) Variation in patients' perceptions of elective percutaneous coronary intervention in stable coronary artery disease: cross sectional study. BMJ 349: g5309.

28. Poses RM, Krueger JI, Sloman S, Elstein AS (2002) Physicians' judgments of survival after medical management and mortality risk reduction due to revascularization procedures for patients with coronary artery disease. Chest 122: 122-133.

29. Cornoiu A, Beischer AD, Donnan L, Graves S, de Steiger R (2011) Multimedia patient education to assist the informed consent process for knee arthroscopy. ANZ J Surg 81: 176-180. [Crossref]

30. Bollschweiler E, Apitzsch J, Obliers R, Koerfer A, Mönig SP, et al. (2008) Improving informed consent of surgical patients using a multimedia-based program? Results of a prospective randomized multicenter study of patients before cholecystectomy. Ann Surg 248: 205-211. [Crossref]

31. Patel V, Aggarwal R, Kinross J, Taylor D, Davies R, et al. (2009) Improving informed consent of surgical patients using a multimedia- based program?: results of a prospective randomized multicenter study of patients before cholecystectomy. Ann Surg 249: 546-547.

32. Eastwood GM (2011) A novel approach to obtaining informed consent from the person responsible: telephone, email and text message. Crit Care Resusc 13: 285. [Crossref]

33. Verges M, Leclercq F, Davy JM, Piot C, Gervasoni R, Pasquie JL, et al. (2011) [Are patients undergoing coronary angiography well-informed? Prospective evaluation of the effectiveness of written information]. Ann Cardiol Angeiol (Paris) 60: 77-86.

34. Miller MJ, Abrams MA, Earles B, Phillips K, McCleeary EM (2011) Improving patient-provider communication for patients having surgery: patient perceptions of a revised health literacy-based consent process. J Patient Saf 7: 30-38.

35. Mishra PK, Mathias H, Millar K, Nagrajan K, Murday A (2010) A randomized controlled trial to assess the effect of audiotaped consultations on the quality of informed consent in cardiac surgery. Arch Surg 145: 383-388. [Crossref]

36. Tait AR, Voepel-Lewis T, Moscucci M, Brennan-Martinez CM, Levine R (2009) Patient comprehension of an interactive, computer-based information program for cardiac catheterization: a comparison with standard information. Arch Intern Med 169: 1907-1914. [Crossref]
37. Steffenino G, Viada E, Marengo B, Canale R (2007) Effectiveness of video-based patient information before percutaneous cardiac interventions. $J$ Cardiovasc Med (Hagerstown) 8: 348-353.

38. Morley CJ1, Lau R, Davis PG, Morse C (2005) What do parents think about enrolling their premature babies in several research studies? Arch Dis Child Fetal Neonatal Ed 90: F225-228. [Crossref]

39. Dathatri S, Gruberg L, Anand J, Romeiser J, Sharma S, et al. (2014) Informed consent for cardiac procedures: deficiencies in patient comprehension with current methods. Ann Thorac Surg 97: 1505-1511.

40. Allmark P, Mason S (2006) Improving the quality of consent to randomized controlled trials by using continuous consent and clinician training in the consent process. $J$ Med Ethics 32: 439-443.

41. AgencyNPS.: http://www.google.co.uk/url?sa=t\&rct=j\&q=consent $\% 20$ in $\% 20$ emer gency $\% 20$ research $\% 20$ information $\% 20$ sheets $\% 20 \% 26 \% 20$ consent $\% 20$ forms $\% 20$ annex $\% 206 \&$ source=web\&cd $=1 \&$ ved $=0 \mathrm{CCkQFjAA} \&$ url $=\mathrm{http} \% 3 \mathrm{~A} \% 2 \mathrm{~F} \% 2 \mathrm{Fwww}$. nres.npsa.nhs.uk\%2FEasysiteWeb\%2Fgetresource.axd\%3FAssetID\%3D338\%26 type \%3DFull\%26servicetype\%3DAttachment\&ei=1JEuT5p346vR \&cad=rja

42. Baren JM, Anicetti JP, Ledesma S, Biros MH, Mahabee Gittens M, et al. (1999) An approach to community consultation prior to initiating an emergency research study incorporating a waiver of informed consent. Acad Emerg Med 6: 1210-1215.

43. Stacey DBC, Barry MJ, Col NF, Eden KB, Holmes- Rovner M, et al. (2011) Decision aids for people facing health treatment or screening decisions. Cochrane Database Syst Rev 5: CD001431

44. Shakur H, Roberts I, Barnetson L, Coats T (2007) Clinical trials in emergency situations. BMJ 334: 165-166. [Crossref]

45. Roberts I, Yates D, Sandercock P, Farrell B, Wasserberg J, et al. (2004) Effect of intravenous corticosteroids on death within 14 days in 10008 adults with clinically significant head injury (MRC CRASH trial): randomised placebocontrolled trial Lancet 364: 1321-1328.

46. Roberts I (2004) Research in emergency situations: with or without relatives consent EMJ 21: 703.

Copyright: (C2018 Khafaji H. This is an open-access article distributed under the terms of the Creative Commons Attribution License, which permits unrestricted use, distribution, and reproduction in any medium, provided the original author and source are credited. 